ISSN 0258-7122 (Print), 2408-8293 (Online)

Bangladesh J. Agril. Res. 42(4): 589-598, December 2017

\title{
REMEDIATION OF HEAVY METAL POLLUTED SOIL THROUGH ORGANIC AMENDMENTS
}

\author{
H. M. NASER ${ }^{1}$, M. Z. RAHMAN ${ }^{2}$, S. SULTANA ${ }^{3}$ \\ M. A. QUDDUS ${ }^{4}$ AND M. A. HAOQUE 5
}

\begin{abstract}
This study was conducted to determine the effects of organic materials to remediate contaminated soil with heavy metals. A pot study was performed by growing maize (Zea mays) in metal contaminated soil $\left(10 \mathrm{~kg} \mathrm{pot}^{-1}\right)$ and soils amendments with cow manure dust, poultry manure dust, vermicompost dust, fern dust, water hyacinth dust, mustard stover dust and barnyard grass dust each at $5 \mathrm{~g} \mathrm{~kg}^{-1}$ soil. The results showed that $\mathrm{Pb}, \mathrm{Cd}, \mathrm{Ni}, \mathrm{Cr}$ and $\mathrm{Co}$ uptake by maize depended on the organic materials type. Water hyacinth dust, fern dust, mustard stover dust, and barnyard grass dust addition led to decreased metal content in maize, and this decrease was better expressed with 20.5 to $33.3 \%$ for fern dust, 17.3 to $22.0 \%$ for water hyacinth, 18.6 to $21.3 \%$ for mustard stover dust, 17.33 to $20.5 \%$ for barnyard grass dust. Cow manure dust, poultry manure dust and vermicompost dust led to increased metal content in the maize, and this increase was 6.80 to $18.7 \%$ for cow manure, 18.9 to $86.7 \%$ for poultry manure and 17.4 to $16.0 \%$ for vermicompost. The different effectiveness of organic amendment on metal uptake by maize plant could be due to the nature of organic matter where water hyacinth dust, fern dust, mustard stover dust, and barnyard grass dust were mainly originated from plant. On the other hand, cow manure, poultry manure and vermicompost were mainly the excreta collected from cattle, poultry and earthworms. However, immobilization and phytoextraction techniques might be used to remediate soils which are contaminated with heavy metal.
\end{abstract}

Keywords: Remediation, heavy metal, organic amendments and maize.

\section{Introduction}

A major environmental concern stemming from the unplanned establishment of industrial units and unscientific disposal of effluent generated by human activities is the contamination of soil and water with salts, metals, organics, and pathogens in developing countries (Ahmad et al., 2011). Land contamination/degradation is a threat to sustainable agricultural development and food security in developing countries. Among all the degraded lands, those contaminated with heavy metals are largely irreversible and where reversibility is attempted, it is at high cost (Oldema, 1994). It has therefore become imperative that the environment and its resources should be managed judiciously to enhance sustainable national and socio-economic development (Adejumo et al., 2011).

${ }^{1}$ Principal Scientific Officer, Soil Science Division, Bangladesh Agricultural Research Institute (BARI), Joydebpur, Gazipur-1701, ${ }^{2}$ Assistant Professor, School of Business Studies, Southeast University, Dhaka, ${ }^{3}$ Scientific Officer, Soil Science Division, BARI, Joydebpur, Gazipur-1701, ${ }^{4}$ Senior Scientific Officer, HRC, BARI, Gazipur-1701, ${ }^{5}$ Chief Scientific Officer, Soil Science Division, BARI, Joydebpur, Gazipur-1701, Bangladesh. 
Toxic metals are biologically magnified through the food chain. They infect the environment by affecting soil properties its fertility, biomass and crop yields and ultimately human health. It is a big issue of accumulation of heavy metals in soils as a result of industrial effluents (Mudgal et al., 2010). With greater public awareness of the implications of contaminated soils on human and animal health there has been increasing interest in developing technologies to remediate contaminated soils.

Addition of organic matter amendments, such as compost, fertilizers and wastes, is a common practice for immobilization of heavy metals and soil amelioration of contaminated soils (Clemente et al., 2005). The effect of organic matter amendments on heavy metal bioavailability depends on the nature of the organic matter, their microbial degradability, salt content and effects on soil $\mathrm{pH}$ and redox potential, as well as on the particular soil type and metals concerned (Walker et al., 2003, 2004).

At least 45 families have been identified to hyperaccumulate heavy metal from soil; some of the families are Brassicaceae, Fabaceae, Euphorbiaceae, Asteraceae, Lamiaceae and Scrophulariaceae. Brassica sp. commonly called Indian mustard; it is a promising plant for phytoremediation (Dushenkov, 2003; Henry, 2000). Aquatic plants such as the floating Eichhornia crassipes (water hyacinth) have been investigated for use in rhizofiltration (Karkhanis et al., 2005). Recently, a fern Pteris vitatta has been shown to accumulate as much as $14,500 \mathrm{mg} \mathrm{kg}^{-1}$ arsenic in fronds without showing symptoms of toxicity (Ma et al., 2001). Large quantities of organic amendments, such as cow manure, water hyacinth compost are used as a source of nutrients and also as a conditioner to improve the physical properties and fertility of soils. These organic amendments can be used as a sink for reducing the bioavailability of heavy metals in contaminated soils through their effect on the adsorption, complexation, reduction and volatilization of metals (Hussain, 2000). The role of organic matter on the metal absorption, transportation and assimilation is known from literature but a little is known about accumulation of heavy metal through organic amendments. For this reason this study was undertaken (i) to evaluate the efficiency of organic amendments as an accumulator for heavy metal in contaminated soil; (ii) to determine the uptake pattern of heavy metal in the tested crop as influenced by various organic amendments; and (iii) to quantify the heavy metal status of polluted soils.

\section{Materials and Methods}

\section{Soil Sampling}

Polluted soil from Kalakoir, Konabari, Gazipur was chosen for the experiment. The site was irrigated with the Turag river water. The river Turag is highly polluted by industrial effluents, sewage sludge, municipal waste water and urban 
pollution. Five composite topsoil samples $(0-20 \mathrm{~cm}$ depth) were randomly collected from farmer's field (10 individual samples). The sampled soil was airdried and passed through a $2 \mathrm{~mm}$ sieve to obtain homogeneous particle size.

\section{Soil and organic amendment preparation}

Two types of organic amendments were used - animal excreta category includes cow manure dust, poultry manure dust and vermicompost dust. And plant materials category includes fern dust, water hyacinth dust, mustard stover dust and barnyard grass dust. The dried organic samples were homogenized by grinding using an electric grinder. Soil samples were mixed by adding organic materials as per treatment at the rate of $5 \mathrm{~g} \mathrm{~kg}^{-1}$ soil. Samples of contaminated soil were thoroughly mixed with the organic amendments resulting in eight treatments: (i) contaminated soil + cow manure dust, (ii) contaminated soil + poultry manure dust, (iii) contaminated soil + vermicompost dust, (iv) contaminated soil + fern dust, (v) contaminated soil + water hyacinth dust, (vi) contaminated soil + mustard stover dust, (vii) contaminated soil + barnyard grass dust, and (viii) contaminated soil as control.

\section{Experiment setup}

The experiment consisted of a total of 24 plastic pots, each containing $10 \mathrm{~kg}$ soil. Pots were placed in a completely randomized design with three replications per treatment at a shade house of Soil Science Division, BARI, Joydebpur, Gazipur. Maize (Zea mays var. BARI hybrid Bhutta-7) seeds were sown directly in pots at a density of 6 seeds per pot on 31 December 2015. Twelve days after sowing the seedlings were thinned to 2 plants per pot. All the pots were fertilized two days before sowing with $\mathrm{N}$ : $90 \mathrm{mg} \mathrm{kg}^{-1}$ soil, $\mathrm{P}: 75 \mathrm{mg} \mathrm{kg}^{-1}$ soil, $\mathrm{K}: 140 \mathrm{mg} \mathrm{kg}^{-1}$ soil, S: $30 \mathrm{mg} \mathrm{kg}$-1 soil, $\mathrm{Zn}: 2 \mathrm{mg} \mathrm{kg}^{-1}$ soil, B: $1 \mathrm{mg} \mathrm{kg}^{-1}$ soil. Urea, triple super phosphate, muriate of potash, gypsum, zinc sulphate monohydrate $\left(\mathrm{ZnSO}_{4} \cdot \mathrm{H}_{2} \mathrm{O}\right)$ and boric acid were used as a source of N, P, K, S, Zn and B, respectively. Nitrogen was applied in two equal splits, the first split before sowing and the remaining splits at 6-8 leaf of plants after sowing. Wetting cycles (at field capacity) and air-drying every week were performed, during a period of about three months.

The plant was harvested at 80 days following seeding, when it had attained reproductive maturity (before flowering). Soil was removed from the roots by careful and plants were washed with tap water followed by deionized water.

\section{Preparation and preservation}

The clean plant samples were air-dried and placed in an electric oven, dried at 85 ${ }^{\circ} \mathrm{C}$ for $72 \mathrm{~h}$, weighed for dry biomass. The dried plant samples were homogenized by grinding using a ceramic coated grinder and used for metal analysis. Samples of contaminated soils were spread on plastic trays and allowed to dry at ambient temperature for 8 days. The dried samples of soils were ground 
with a ceramic coated grinder and sieved through a nylon sieve. The final samples were kept in labeled polypropylene containers at ambient temperature before analysis.

\section{Digestion and Analytical Procedure}

One gram of each sample was weighed into 50-ml beakers, followed by the addition of $10 \mathrm{ml}$ mixture of analytical grade acids $\mathrm{HNO}_{3}: \mathrm{HCIO}_{4}$ in the ratio 5:1, and left overnight for complete contact of material. Next day, the digestion was performed at a temperature of about $190{ }^{\circ} \mathrm{C}$ for $1.5 \mathrm{~h}$. After cooling, the samples were transferred into $100 \mathrm{ml}$ volumetric flask and solution was made up to a final volume raised up to the mark with distilled water. The metal concentrations were determined by atomic absorption spectrometry using a VARIAN model AA2407 Atomic Absorption Spectrophotometer (AAS). Analysis of each sample was carried out three times to obtain representative results and the data reported in $\mu \mathrm{g}$ $\mathrm{g}^{-1}$ (on a dry matter basis).

\section{Bioconcentration factor (BCF)}

To compare the accumulation and transfer of metals in the different plant parts and soils, two indices were calculated according to the procedure described by $\mathrm{Li}$ et al. (2009). The bioconcentration factor (BCF) was calculated according to the following equation:

$\mathrm{BCF}=[\mathrm{M}$ stem or $\mathrm{M}$ leaves or $\mathrm{M}$ root $] /[\mathrm{M}$ soil $]$

\section{Statistical analysis}

The experiment was designed in completely randomized (CRD) with 8 treatments and three replications. Treatment effects were determined by analysis of variance with the help of statistical package STATISTIX-10 and mean separation was tested by Tukey HSD.

\section{Results and Discussion}

The results of pre-potting soil analyses are presented in Table 1. Nickel (Ni) and chromium $(\mathrm{Cr})$ occurred in greater concentrations than those lead $(\mathrm{Pb})$, cadmium (Cd) and cobalt (Co). The concentration of $\mathrm{Pb}$ was $17.8 \mu \mathrm{g} \mathrm{g}^{-1}, \mathrm{Cd}-1.76 \mu \mathrm{g} \mathrm{g}^{-1}$, $\mathrm{Ni}-41.3 \mu \mathrm{g} \mathrm{g}^{-1}, \mathrm{Cr}-33.7 \mu \mathrm{g} \mathrm{g}^{-1}$ and $\mathrm{Co}-15.0 \mu \mathrm{g} \mathrm{g}^{-1}$. These levels $(\mathrm{Cd}, \mathrm{Ni}$ and $\mathrm{Cr})$ were extremely high when compared with the levels of these metals in uncontaminated soil reported by Bowen (1966), except Pb.

Metal content of different applied organic materials are presented in Table 2. The effects of the organic material applications on uptake levels of $\mathrm{Pb}, \mathrm{Cd}, \mathrm{Ni} \mathrm{Cr}$ and Co from the contaminated soil samples by maize are given in Table 3 . The results indicated that application of organic material originated from plant materials corresponded to a reduction of levels of metals uptake by the maize plants. On the other hand, the metal contents of maize were elevated by the application of 
animal excreta. Putwattana et al. (2010) found a significant increase in shoot Cd concentration and the total Cd uptake of plants when cow manure was applied. Similar result was also observed by Awotoye et al. (2011).

Table 1. Initial heavy metal status of the industrial effluents polluted soil used in potting media

\begin{tabular}{c|c|c|c|c|c}
\hline \multirow{2}{*}{ Soil heavy metal } & \multicolumn{5}{|c}{ Heavy metals content $\left(\mu \mathrm{g} \mathrm{g}^{-1}\right)$ of soil samples } \\
\cline { 2 - 6 } & $\mathrm{Pb}$ & $\mathrm{Cd}$ & $\mathrm{Ni}$ & $\mathrm{Cr}$ & $\mathrm{Co}$ \\
\hline Result & $17.8 \pm 2.59$ & $1.76 \pm 0.50$ & $41.3 \pm 5.51$ & $33.7 \pm 4.39$ & $15.0 \pm 1.70$ \\
\hline Uncontaminated soil $^{\mathrm{a}}$ & 100 & 3 & 50 & 100 & 50 \\
\hline Uncontaminated soil $^{\mathrm{b}}$ & 50 & 1 & 1 & 30 & - \\
\hline
\end{tabular}

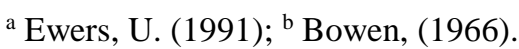

Table- 2. Metal content of different applied organic materials

\begin{tabular}{c|c|c|c|c|c}
\hline \multirow{2}{*}{ Materials } & \multicolumn{5}{c}{ Concentration $\left(\boldsymbol{\mu g} \mathbf{g}^{-1} \mathbf{d r y}\right.$ wt.) } \\
\cline { 2 - 6 } & $\mathbf{P b}$ & $\mathbf{C d}$ & $\mathbf{N i}$ & $\mathbf{C r}$ & $\mathbf{C o}$ \\
\hline Cow manure dust & 5.21 & 0.36 & 4.70 & 3.52 & 5.80 \\
Poultry manure dust & 9.3 & 0.60 & 6.20 & 6.78 & 8.60 \\
Vermicompost dust & 10.3 & 0.42 & 11.4 & 8.32 & 9.15 \\
\hline \multirow{5}{*}{ Fern dust } & 2.40 & 0.25 & 5.90 & 2.50 & 3.22 \\
\hline Water hyacinth dust & 2.56 & 0.39 & 4.22 & 3.10 & 4.43 \\
Mustard stover dust & 1.14 & 0.36 & 6.10 & 1.98 & 3.30 \\
Barnyard grass dust & 1.16 & 0.22 & 3.50 & 2.00 & 2.71 \\
\hline
\end{tabular}

If plant uptake levels adequately described the effectiveness of metal immobilization, the results in Table 2 suggest that the effectiveness of immobilization varied in the order of water hyacinth dust $>$ fern dust $>$ mustard stover dust > barnyard grass dust. Metal content increased in maize by addition of animal excreta was doubles as compared to the plant materials application.

Narwal and Singh (1998) reported a significant increase in metal concentration in wheat when pig manure was the organic matter (OM) source. On the contrary, organic amendment such as cow or pig manure can decrease the bioavailability of heavy metals in soil (Tordoff et al., 2000). Organic matter has been reported to show different effects on metal extractability, which may depend on the sources of OM, rate and plant species (Angelova et al., 2010). The different effectiveness 
of organic amendment on metal uptake by maize plant in our study could be possible due to the nature of organic matter where water hyacinth dust, fern dust, mustard stover dust, and barnyard grass dust were mainly originated from plant. On the other hand, cow manure, poultry manure and vermicompost are mainly the excreta collected from animal.

Table 3. Effect of organic amendment application on metal content by maize from contaminated soil

\begin{tabular}{|c|c|c|c|c|c|}
\hline \multirow{2}{*}{$\begin{array}{l}\text { Applied material } \\
\left(5 \mathrm{~g} \mathrm{~kg}^{-1} \text { soil }\right)\end{array}$} & \multicolumn{5}{|c|}{$\begin{array}{c}\text { Level of metal content ( } \pm \text {, standard deviation) by maize ( } \mu \mathrm{g} \mathrm{g}^{-1} \\
\text { of dry wt.) }\end{array}$} \\
\hline & $\mathbf{P b}$ & Cd & $\mathbf{N i}$ & $\mathrm{Cr}$ & Co \\
\hline $\begin{array}{l}\text { Contaminated } \\
\text { control }\end{array}$ & $5.20 \pm 0.77 \mathrm{ab}$ & $0.75 \pm 0.14 b c$ & $26.4 \pm 1.25 \mathrm{abc}$ & $16.6 \pm 3.44 b c$ & $4.61 \pm 1.13 \mathrm{ab}$ \\
\hline \multicolumn{6}{|c|}{ Animal excreta } \\
\hline Cow manure dust & $4.81 \pm 0.17 \mathrm{abc}$ & $0.89 \pm 0.27 \mathrm{ab}$ & $28.2 \pm 2.44 \mathrm{ab}$ & $21.3 \pm 2.29 b$ & $4.60 \pm 1.12 \mathrm{ab}$ \\
\hline Poultry manure dust & $6.34 \pm 0.58 \mathrm{a}$ & $1.40 \pm 0.17 \mathrm{a}$ & $31.4 \pm 5.22 \mathrm{a}$ & $33.6 \pm 4.59 \mathrm{a}$ & $6.14 \pm 1.47 \mathrm{a}$ \\
\hline Vermicompost dust & $5.04 \pm 0.72 \mathrm{ab}$ & $1.32 \pm 0.28 \mathrm{a}$ & $31.0 \pm 2.85 \mathrm{a}$ & $26.1 \pm 6.86 \mathrm{ab}$ & $5.44 \pm 1.64 \mathrm{a}$ \\
\hline \multicolumn{6}{|c|}{ Plant materials } \\
\hline Fern dust & $3.26 \pm 0.70 \mathrm{c}$ & $0.62 \pm 0.11 b c$ & $21.0 \pm 1.39 \mathrm{bc}$ & $10.4 \pm 0.93 \mathrm{c}$ & $2.18 \pm 0.32 b c$ \\
\hline Water hyacinth dust & $3.16 \pm 0.51 \mathrm{c}$ & $0.50 \pm 0.10 \mathrm{c}$ & $20.6 \pm 1.33 c$ & $8.49 \pm 2.25 \mathrm{c}$ & $1.64 \pm 0.24 \mathrm{c}$ \\
\hline Mustard stover dust & $3.29 \pm 0.57 \mathrm{c}$ & $0.59 \pm 0.08 b c$ & $21.5 \pm 1.78 b c$ & $8.03 \pm 2.76 \mathrm{c}$ & $2.20 \pm 0.84 b c$ \\
\hline Barnyard grass dust & $3.84 \pm 0.59 b c$ & $0.62 \pm 0.09 b c$ & $21.2 \pm 1.95 \mathrm{bc}$ & $10.4 \pm 1.38 \mathrm{c}$ & $2.30 \pm 0.42 b c$ \\
\hline $\mathrm{CV}(\%)$ & 13.8 & 20.2 & 10.3 & 21.0 & 28.2 \\
\hline
\end{tabular}

Mean values in the same column followed by the same letters are not significantly different $(P<0.05)$.

The metal concentrations decreased in maize plant with the addition of water hyacinth dust, fern dust, mustard stover dust, and barnyard grass dust, which might have immobilized the metal through adsorption, complexation, and precipitation phenomena, resulting in reduced phytotoxicity and accumulation in plants (Cao et al., 2003; Geebelen et al., 2002; Seaman et al., 2003). According to the literature the content of organic substance in soil has a significant impact on absorption and translocation of heavy metals in soil and their uptake by plants. Metals $(\mathrm{Cu}, \mathrm{Zn}, \mathrm{Pb}$ and $\mathrm{Cd})$ are adsorbed on organic matter, which generate stable forms and lead to their accumulation in organic horizons of soil (KabataPendias, 2001). The results obtained by us showed that $\mathrm{Pb}, \mathrm{Cd}, \mathrm{Ni}, \mathrm{Cr}$ and $\mathrm{Co}$ uptake by maize depended on the organic materials type. 
Table- 4. Metal uptake decreased in maize compared with contaminated control

\begin{tabular}{|c|c|c|c|c|c|}
\hline \multirow{2}{*}{$\begin{array}{l}\text { Applied } \\
\text { material } \\
\left(5 \mathrm{~g} \mathrm{~kg}^{-1} \text { soil }\right)\end{array}$} & \multicolumn{5}{|c|}{ Metal uptake decreased $(\%)$ compared with contaminated control } \\
\hline & $\mathbf{P b}$ & Cd & $\mathbf{N i}$ & $\mathrm{Cr}$ & Co \\
\hline \multirow[t]{2}{*}{ Metal aspect } & 7.36 to 22.0 & 32.0 to 86.8 & 7.0 to 19.1 & 29.0 to 103 & $\begin{array}{l}(-0.28) \text { to } \\
33.1\end{array}$ \\
\hline & Cow manure & $\begin{array}{l}\text { Poultry } \\
\text { manure }\end{array}$ & Vermicompost & - & - \\
\hline $\begin{array}{l}\text { Animal } \\
\text { excreta }\end{array}$ & $6.80-18.7$ & $18.9-86.7$ & $16.0-17.4$ & - & - \\
\hline \multirow{2}{*}{$\begin{array}{l}\text { Applied } \\
\text { material } \\
\left(5 \mathrm{~g} \mathrm{~kg}^{-1} \text { soil }\right)\end{array}$} & \multicolumn{5}{|c|}{$\begin{array}{c}\text { Metal uptake decreased }(\%) \text { in maize compared with contaminated } \\
\text { control }\end{array}$} \\
\hline & $\mathrm{Pb}$ & $\mathrm{Cd}$ & $\mathrm{Ni}$ & $\mathrm{Cr}$ & Co \\
\hline \multirow[t]{2}{*}{ Metal aspect } & 26.3 to 39.1 & 17.3 to 33.5 & 18.2 to 21.8 & 37.3 to 46.0 & 50.0 to 64.5 \\
\hline & Fern & $\begin{array}{c}\text { Water } \\
\text { hyacinth }\end{array}$ & Mustard stover & $\begin{array}{l}\text { Barnyard } \\
\text { grass }\end{array}$ & - \\
\hline $\begin{array}{l}\text { Plant } \\
\text { materials }\end{array}$ & $20.5-33.3$ & $17.3-22.0$ & $18.6-21.3$ & $17.3-20.5$ & - \\
\hline
\end{tabular}

Table 5. Bioconcentration factor of heavy metals from soil to maize plant as influenced by organic material applications

\begin{tabular}{c|c|c|c|c|c}
\hline \multirow{2}{*}{ Applied material } & \multicolumn{5}{|c}{ Name of metal } \\
\cline { 2 - 6 } & $\mathbf{P b}$ & $\mathbf{C d}$ & $\mathbf{N i}$ & $\mathbf{C r}$ & $\mathbf{C o}$ \\
\hline $\begin{array}{c}\text { Contaminated } \\
\text { control }\end{array}$ & 0.292 & 0.426 & 0.638 & 0.493 & 0.308 \\
\hline \multicolumn{5}{c}{ Animal excreta } \\
\hline $\begin{array}{c}\text { Cow manure dust } \\
\text { Poultry manure } \\
\text { dust }\end{array}$ & 0.271 & 0.562 & 0.682 & 0.633 & 0.307 \\
$\begin{array}{c}\text { Vermicompost } \\
\text { dust }\end{array}$ & 0.357 & 0.795 & 0.760 & 0.998 & 0.410 \\
\hline \multicolumn{7}{c}{ Fern dust } \\
$\begin{array}{c}\text { Water hyacinth } \\
\text { dust }\end{array}$ & 0.184 & 0.753 & 0.749 & 0.776 & 0.363 \\
$\begin{array}{c}\text { Mustard stover } \\
\text { dust }\end{array}$ & 0.178 & 0.283 & 0.499 & 0.252 & 0.109 \\
$\begin{array}{c}\text { Barnyard grass } \\
\text { dust }\end{array}$ & 0.216 & 0.352 & 0.509 & 0.146 \\
\hline
\end{tabular}


The percentage $(\%)$ of metal uptake decreased in maize with addition of plant originated organic material compared with contaminated control were $\mathrm{Pb}-26.3$ to $39.1, \mathrm{Cd}-17.3$ to $33.5, \mathrm{Ni}-18.2$ to $21.8, \mathrm{Cr}-37.3$ to 46.0 and $\mathrm{Co}-50.0$ to 64.5. It was $\mathrm{Pb}-7.36$ to $22.0, \mathrm{Cd}-32.0$ to $86.8, \mathrm{Ni}-7.0$ to $19.1, \mathrm{Cr}-29.0$ to 103 and $\mathrm{Co}-(-0.28)$ to 33.1 increment in animal excreta application treatments (Table 4). Water hyacinth dust, fern dust, mustard stover dust, and barnyard grass dust addition led to decreased metal content in maize, and this decrease was better expressed with 20.5 to $33.3 \%$ for fern dust, 17.3 to $22.0 \%$ for water hyacinth, 18.6 to $21.3 \%$ for mustard stover dust, 17.3 to $20.5 \%$ for barnyard grass dust. Cow manure dust, poultry manure dust and vermicompost dust led to increased metal content in the maize, and this increase was best expressed with 6.80 to $18.7 \%$ for cow manure, 18.9 to $86.7 \%$.for poultry manure and 16.0 to $17.4 \%$ for vermicompost. Addition of organic materials to contaminated soil did not totally restrict the uptake of metal by maize plants but the total level recorded in the plant tissues from all the plant originated organic materials treated plants were significantly lower than those treated with animal excreta and contaminated control. The present study found a significant increase in metal uptake of plants when animal excreta were applied.

Soil-to-plant transfer ratio (amount of metal in plant to the pseudo-total amount in soil) or Bioconcentration factor $(\mathrm{BCF})$ is an important aspect of phytoextraction. The effect of the organic amendment application on the BCF of metals from the contaminated soil to maize is shown in Table 5. As with the amounts of the metals uptake by maize, the proportions of the metals in the soil that were absorbed by the plants decreased with applications of organic amendments and were water hyacinth dust $>$ fern dust $>$ mustard stover dust > barnyard grass dust. The highest values of TC (0.998) was found in plant grown in poultry manure dust treatment and lowest was in water hyacinth dust treatment. Putwattana et al. (2010) reported that sweet basil (Ocimum basilicum) grown in $\mathrm{Cd}$ contaminated soil and soil amendments with animal excreta (cow manure) showed increases in TF values with the exposure time.

\section{Conclusion}

Application of plant originated organic materials has been shown to immobilize metals in soil and decreased the metal content of plants. On the other hand, animal excreta had significant impact on phytoextraction of metal from soil. Immobilization and phytoextraction techniques might be used to remediate soil contaminated with metal. The plant originated organic amendments are of great interest for the purpose of phytostabilization. Evaluation of their potential, however, requires further study of the effect of organic amendments on a wider range of agricultural crops. 


\section{References}

Adejumo, S. A., A. O. Togun, J. A. Adediran and M. B. Ogundiran. 2011. In-Situ Remediation of Heavy Metal Contaminated Soil Using Mexican Sunflower (Tithonia diversifolia) and Cassava Waste Composts. World Journal of Agricultural Sciences. 7(2): 224-233.

Ahmad, H.R., A. Ghafoor, D. L. Corwin, M. A. Aziz, Saifullah, and M. Sabir. 2011. Organic and Inorganic Amendments Affect Soil Concentration and Accumulation of Cadmium and $\mathrm{R}$

Angelova, V., R. Ivanova, G. Pevicharova, and K. Ivanov. 2010. Effect of organic amendments on heavy metals uptake by potato plants. 19th World Congress of Soil Science, Soil Solutions for a Changing World. 1 - 6 August 2010, Brisbane, Australia.

Awotoye, O.O., D. J. Oyedele and B. C. Anwadike. 2011. Effects of cow-dung and rock phosphate on heavy metal content in soils and plants. Journal of Soil Science and Environmental Management. 2(7): pp. 193-197.

Bowen, H. J. M. 1966. Trace Elements in Biochemistry (p. 241). New York: Academic.

Cao, X., L. Q. Ma and A. Shiralipour. 2003. Effects of compost and phosphate amendments on arsenic mobility in soils and arsenic uptake by the hyper accumulator, Pteris vittata L. EnvironmentalPollution. 126: 157-167.

Clemente, R., D. J. Waljker and M. P. Bernal 2005. Uptake of heavy metals and As by Brassica Juncea grown in a contamination soil in Arnalcollar (Spain): The effect of soil amendments. Environmental Pollution. 136:46-58.

Dushenkov, D. 2003. Trends in phytoremediation of radionuclides. Plant and Soil. 249: 167-175.

Geebelen, W., J. Vangronsveld, D. C. Adriano, R. Carleer and H. Clijsters. 2002. Amendment induced immobilization of lead in a lead spiked soil: Evidence from phytotoxic studies. WaterAir Soil Poll. 140: 261-277.

Henry J. R. 2000. In An Overview of Phytoremediation of Lead and Mercury. NNEMS Report. Washington, D.C.; pp, 3-9.

Hussain, S. I. 2000. Irrigation of crops with sewage effluent: Implication and movement of $\mathrm{Pb}$ and $\mathrm{Cr}$ as affected by soil texture, lime, gypsum, and organic matter. $\mathrm{PhD}$ thesis, Apartment of Soil Science, University of Agriculture, Faisalabad, Pakistan.

Kabata-Pendias A. 2001. Trace Elements in Soils and Plants, 3rd ed. CRC Press LLC, Boca Raton. Salt DE, Smith RD, Raskin I (1998) Phytormediation. Annual Rev. Plant Physiol. Plant Molecular Biology. 49: 643-668.

Karkhanis, M., C. D. Jadia, M. H. Fulekar. 2005. Rhizofilteration of metals from coal ash leachate. Asian J Water Environ Pollution. 3(1):91-94.

Ma, L.Q., K. M. Komar, C. Tu, W. Zhang, Y. Cai and E. D. Kennelley. 2001. A fern that hyperaccumulates arsenic. Nature. 409: 579.

Li, N.Y., Z. A. Li, P. Zhuang, B. Zou and M. Mcbride. 2009. Cadmium uptake from soil by maize with intercrops. Water, Air, Soil Pollution. 199:45-56. 
Mudgal, V., N. Madaan and A. Mudgal. 2010. Heavy metals in plants: phytoremediation: Plants used to remediate heavy metal pollution. Agriculture and Biology Journal of North America. 1(1): 40--46.

Narwal R. P. and B. R. Singh. 1998. Effect of organic materials on partitioning, extractability and plant uptake of metals in an alum shale soil. Water, Air, and Soil Pollution 103: 405-421.

Oldema, L.R. 1994. The global extent of soil degradation. In Greenland, D.J. and Szaboles T. (eds). Soil Resilience and Sustainable Land Use. Wallingford, Commonwealth Agricultural Bureau International http://www. Isric.nl/GLASOD.htm

Putwattanaa, N., M. Kruatrachue, P. Pokethitiyooka and R. Chaiyaratc. 2010. Immobilization of cadmium in soil by cow manure and silicate fertilizer, and reduced accumulation of cadmium in sweet basil (Ocimum basilicum). ScienceAsia. 36: 349354.

Seaman, J. C., J. M. Hutchison, B. P. Jackson and V. M. Vulava. 2003. In situ treatment of metals in contaminated soils with phytate. Journal of Environmental Quality 32:153-161.

Tordoff, G.M., A. J. M. Baker, A. J. Willis. 2000. Current approaches to the revegetation and reclamation of metalliferous mine wastes. Chemosphere. 41: 219-228.

Walker, D.J., R. Clemente, A. Roig and M. P. Bernal. 2003. The effect of soil amendments on heavy metal bioavailability in two contaminated Mediterranean soils. Environ Pollution. 22: 303-312.

Walker, D.J., R. Clemente and M. P. Bernal. 2004. Contrasting effects of manure and compost on soil $\mathrm{pH}$, heavy metal availability and growth of Chenopodium album L. in a soil contaminated by pyritic mine waste. Chemosphere. 57: 215-224. 